\title{
Specialized Construction of College Counselors in the Perspective of Ecosystem
}

\author{
Yang Li, Zhenxiang Tian,* \\ Zaozhuang University \\ Zaozhuang, China \\ 1489200495@qq.com
}

\begin{abstract}
In recent years, the construction of the counselor specialization in Colleges and universities in China has become ecologically unbalanced. This paper expounds the connotation of the ecological system in colleges and universities, from the perspectives of management responsibility examination, and discusses the construction of college counselor specialization ecosystem theory reflection on the current path of specialization construction of university counselors to provide us with a new perspective of the counselor team construction.
\end{abstract}

Keywords-Ecosystem; Counselor; Specialization; Ecological imbalance; Ways to achieve

\section{INTRODUCTION}

College counselors are an important part of the university faculty. They are both university teachers and administrators. With the progress of college education reform in China, college counselors have become more and more important, their identity roles have become more and more blurred, and the scope of work has become increasingly larger. This poses new challenges for college counselors. College counselors bring conflicts and confusion in their own roles at work. Although the new situation requires college counselors to possess higher professional qualities, not only should they have a good level of political theory and management skills, but they must also have knowledge and skills in sociology, psychology, etc., but on the other hand, China's current The professional construction of college counselors lags behind, which leads to the increasingly prominent contradiction between job requirements and the professional qualities of on-the-job staff. Under this circumstance, the Ministry of Education successively promulgated the Opinions on Strengthening the Construction of Counselors and Head Teachers in Colleges and Universities and the Provisions on the Construction of Counselors for Colleges and Universities, and proposed that the construction of college counselors should be "professionalized and expert." The direction of development, colleges and universities should be based on the needs of the situation with a sufficient number of counselors and headteachers, to college counselors in the construction of special requirements put forward specific requirements [1].

\section{The NeCEsSITY OF PROFESSIONALIZATION OF COLLEGE COUNSELORS IN THE PERSPECTIVE OF ECOSYSTEM}

\section{A. Interpretation of the Connotation of Ecosystem in Colleges and Universities}

The theory of ecosystems was put forward by the famous psychologist Brown Fenner. He believes that the development of individual development is affected by the environment. The environment (or the natural ecology) is a set of nested structures, each nested in the next one. It's like a Russian doll." In other words, the developing individual is in or nested within several environmental systems from the immediate environment (like the family) to the indirect environment (like a broad culture), which interacts with the individual and influences the individual development. The university is also an ecological system with "comprehensive environmental benefits" that consists of multiple elements. As for each individual tutor, the whole society is the macroscopic environment of the system. The overall educational strength, environment, and system of each college and university. The management mechanism is the outer environment of the system. Senior leaders and full-time teachers in colleges and universities belong to the intermediate system. The counselor team composed of counselors is the microsystem of the system. These four different levels of the system are bound to counselors. Individual development has different effects. In turn, the professional development and construction of the counselor will have different degrees of impact on the other three external system environments. They are mutually rented. To view the construction of college counselors' specialization based on the theory of ecosystem is to use ecological knowledge and culture as a guide to promote the virtuous circle of higher education practice, so as to realize the comprehensive benefits of college education ecology in the cultural ecology consciousness. 


\section{B. The Necessity of Professionalization of College Counselors}

a) To improve the professionalization level of college counselors is a need to adapt to the development of educational ecosystems in colleges and universities.

With the ever-increasing enrollment and competition in higher education in our country, the quality and level of higher education have been improved. At the same time, higher education is no longer like a godsend that once was regarded as a self-improvement, it has become a commodity that needs to accept market choices. People began to pursue higher quality and richer educational resources in a large number of higher education resources. This requires colleges and universities not only to upgrade themselves in "hard power" in universities, but also to provide good teaching, teaching staff, books and other venues and hardware equipment, but also to invest heavily in soft power, and to upgrade the level of education, management, and services. Do it scientifically and humanely to form its own characteristics and system. Under this background, the traditional administrative methods of colleges and universities must constantly change the management functions, perform more service functions, continue to refine the work, and implement refined management, so as to meet the increasingly urgent individualized development needs of the students. Adapt to the Development Law of College Education Ecosystem. This is also an important reason why the research on the professionalization of the tutors is highly valued and formed by the universities.

b) The improvement of the professionalization level of college counselors is the improvement of the effectiveness of ideological and political education in colleges and universities

The counselor is the main body of university ideological and political education, which determines one of its professional characteristics is the political nature of the goal. The professional goals of counselors are political, which is the embodiment of the class nature of ideological and political education [2]. The state has targeted expectations for the ideological and political work of the counselors. It must guide students through their healthy growth and eventually train them into qualified successors of the socialist cause and promote the development of the socialist cause. University is the period of the final development, formation and determination of human values. Therefore, the level of professionalization of college counselors is directly related to the level of ideological and political education of college students, and the professional construction of the team of counselors is conducive to changing the traditional empirical and extensive style. The education ecology and management model of colleges and universities form a scientific and refined training model, constantly exploring new experiences in education, management, and team building, so that the counselors can continuously enhance their learning, improve their professionalism, and achieve their ideological and political education. Keeping up with the times and achieving good results.

\section{ANALYSIS OF ECOLOGICAL UnBALANCE EXISTING IN THE PROFESSIONAL CONSTRUCTION OF UNIVERSITY COUNSELORS}

With the continuous advancement of China's college education reform, the professionalization of college counselors has gradually begun to receive attention. Many colleges and universities have carried out explorations in terms of functions, systems, and measures, and have achieved certain results, but overall there are still various There are various problems, some of which are due to lack of understanding, some because of loose management, and are generally expressed in the following aspects.

\section{A. Some colleges and universities have neglected the importance of the counselor's work, and did not attach importance to the professionalization of the counselor}

Due to the constraints of external utilities such as the size of the school, university rankings, and landmark achievements, many universities and colleges place teaching and research as their top priorities. All other work in the school is centered on teaching and research services. This has led many colleges and universities to neglect the ideological and political work of students and to create an ecological balance between the professionalization and professionalization of university teachers. This kind of imbalance was first reflected in the lack of attention to the work of counselors. Although the job responsibilities, the counselor's job is not only to manage college students' daily lives and behavioral habits, to promptly solve and solve college students' psychological puzzles and various difficulties, more importantly, to shoulder the important task of ideological and moral education for college students. According to a survey of 100 counselors from 4 universities in Xingtai, Hebei, $35 \%$ of the counselors believe that their primary responsibility is to do a good job of ideological and political education for students, manage their daily life, and guide their overall ability. This shows that many college counselors can identify with their initial duties, but in actual work, many colleges and universities will simplify the job responsibilities of counselors as student accommodation management and teaching assistants, and are treated as "second class teachers". However, in the absence of attention, coupled with a variety of tedious affairs, counselors have misunderstood their own job responsibilities, resulting in job burnout, it is reasonable. Secondly, this kind of imbalance is also reflected in the lack of attention to the training and promotion of counselors, which limits their professional development. On the one hand, colleges and universities rarely provide counselors with training and learning opportunities. On the other hand, they are inclined to full-time professors and leaders in terms of salary and benefits, promotion of titles, and training and training. This prevents them from updating their concepts and improving the management of students. Method. 
B. The responsibilities of counselors in some colleges and universities are too heavy which exceed the carrying capacity of counselors

At present, many colleges and universities do not have a clear position and scope concerning the responsibility of the counselor. Under such circumstances, all matters related to the teaching are handed over to or handled by the counselor, whether it is from school to event or small to health. Cleanliness, no matter how big, are the responsibility of the counselor. They are the communicators of the orders of the superior, the organisers of the activities, the nannies of the students, the supervisors of the examinations, the instructors of the study, and the doctors of psychological counseling. Career planners, etc. This unlimited expansion of responsibilities often leads the counselors to split their spells and become exhausted, leaving them with less time to study their own jobs and improve their academic and personal qualities. When this kind of responsibilities expands beyond its capacity, it will neglect its own job. Because the students' ideological and political education cannot penetrate in depth, they can only be in form or completely out of touch with reality. Another direct effect of this serious imbalance in workload is that many counselors are overwhelmed by the burden, so they only use it as a springboard and lack the real love and recognition for their work. Once they have the opportunity, they will turn to it. Other administrative posts or teaching posts have made the construction of counselors team always in an unstable state of rapid renewal. Newly recruited tutors are often master graduates who have just graduated from school. They lack the corresponding knowledge structure and social experience and are unable to become college students. The guides and mentors are also specialized in the construction of counselors.

\section{Unreasonable management institutions and mechanisms in universities are not conducive to the development of the enthusiasm of counselors}

Colleges and universities generally have institutions such as admissions office, student affairs office, and party affairs office. These agencies directly give counselors the task of managing student affairs and supervise the work of counselors. The counselor management organization will follow the counselor's management guidelines and Schedule to release work instructions. Due to the fact that the scope of work of the counselors in our country is basically conducted around the hospitals, departments, and dormitories, many colleges and universities lack the specific assessment methods for the counselors and the management assessment system formulated is not perfect. This can easily lead to conflict and confusion in the work between schools and colleges. Coupled with the phenomenon of self-government, it sometimes requires a lot of coordination work. Due to the lack of a sound assessment and evaluation mechanism, many counselors do not receive due value in terms of their job title and treatment. On the other hand, because of their relationships, some of them may not be able to go through jobs after assessment, and even open back doors for job titles. Shortcuts, rewards and penalties, promotion, hiring, and assessment are decoupled. This causes you to undermine the ecological balance of counselors' internal competition and to effectively mobilize the enthusiasm of counselors. Obstructed its specialization.
IV. WAYS TO ACHIEVE THE PROFESSIONALIZATION OF EFFECTIVE COUNSELORS IN THE PERSPECTIVE OF ECOSYSTEMS

\section{A. Change ideological concepts and innovative management methods}

Colleges and universities should actively change traditional concepts and fully recognize the important role of the counselors. Only by giving full play to the key role of their ideological and political education, they can give full play to the organization, implementation, and guidance of their daily education and management, and give full play to the life of college students. The role of mentors and healthy and growing close friends can achieve the goal of maintaining the stability of universities and society, guaranteeing the sustained and healthy development of higher education, and training qualified constructors and reliable successors of the cause of socialism with Chinese characteristics. Colleges and universities should regard strengthening the construction of counselors as a longterm, overall and strategic major political task. They should actively formulate policies, take measures, and do a good job of implementation.

In management, colleges and universities can implement dual leadership systems for schools and colleges. The school party committee is mainly responsible for the unified planning, leadership, and management of the construction of the counselor team. All colleges and universities (colleges) must establish and improve the student work organization, with the sub-committee of the Party committee in charge of the ideological and political education of students, the colleges and universities (divisions) sub-committee to directly manage and lead the counselors under their jurisdiction, and at the same time the university management department It is necessary to emancipate the mind, change the functions, change the mode of management, realize the transition from management to staffcoordination, and transition from direct administrative management to target management, and strengthen communication and coordination between schools and colleges.

\section{B. Reasonable division of responsibilities and emphasis on instructor training}

Reasonable division of the scope of the counselor's duties means that the counselor is properly positioned. Colleges and universities should make clear their core work ideological and political work of college students, its main work is to guide the development of students, its basic work when the management of student affairs. Therefore, the counselor is first and foremost a guide for college students. Counselors should carry out various policies and special education activities according to the changes in students' ideological and political situations; secondly, the counselors are the supporters of the university's fertility development. He should actively organize college students to establish various grass-roots organizations, do a good job in the construction of student caucus, classes, and community organizations, and guide students in self-education, self-management, and self-service. The second counselor is a service provider for college students. It should actively do a good job in daily service work, including helping students to help with difficulties, mental health counseling, career choices and friends. 
At the same time, colleges and universities should formulate counselors training and development plans, and establish multi-level and multi-form training systems such as counselor induction training, daily training, vocational training, and special training. For newly elected counselors, we must insist on training first, post-up, and strict admission system. It is necessary to organize counselors to participate in international and domestic exchanges, inspections, and advanced studies, and encourage and support full-time counselors to study master's and doctoral degrees in related fields, and become ideological and political education, mental health education, career planning, and student affairs management. Specialized personnel have long been engaged as counselors. Full-time instructors who are studying for degree and domestic and foreign business training should be included in the school teacher planning and talent training plan, and enjoy the same treatment and relevant encouragement policies for school full-time teachers [4].

\section{Strengthen the system construction and improve the assessment system}

Colleges and universities shall, in accordance with the duties of counselors, formulate specific assessment methods for counselors and improve the management and assessment system for counselors. The assessment of the counselor is jointly attended by the student work department, the organization personnel department, the college (department) and students. The assessment results should be linked to job appointment, reward, punishment, and promotion. Unskilled counselors should promptly move away from the counselor's work position. The awards and rewards for outstanding instructors should be included in the commendation and reward system for teachers and educators. It is necessary to establish a group of excellent instructors and publicize their advanced deeds.

\section{CONCLUSION}

To achieve effective professional instructor construction, we must always start from the entire university in the work, proceed from the development of colleges and universities, grasp the ecological balance of university education work in practical work, and scientifically and reasonably position the work responsibilities and scope of the counselor, so that the The professionalization of the staff takes a professional and sustainable development [3].

\section{REFERENCES}

[1] Wang Suling. Eco-philosophy view of higher education ecology [J]. Journal of Anhui Agricultural University, 2007 (6): 97 100.

[2] Complete Works of Marx and Engels (Vol. 19) [M]. Beijing: People's Publishing House 1956.406.

[3] Qin Haifen. Thinking on the professionalization of college counselors. [D] East China Normal University, 2009

[4] Su Yala Tu. Research on the Innovation of Ideological and Political Education for University Students in Ethnic Regions: Taking the Universities of Inner Mongolia Autonomous Region as an Example.[D]. Inner Mongolia University, 2013. 